\title{
The Effectiveness of Cognitive Restructuring Techniques in Improving Students Learning Motivation
}

\author{
Laily Puji Astuti ${ }^{1}$, Muhammad Nur Wangid \\ Universitas Negeri Yogyakarta, Indonesia \\ Qlailyastuti@yahoo.co.id ${ }^{1}$
}

\section{Article Information:}

Received December 15, 2019

Revised February 16, 2020

Accepted February 21, 2020

Keywords: cognitive

restructuring techniques; group

counseling; students learning

motivation

\begin{abstract}
The aim of the research is to determine the effectiveness of cognitive restructuring techniques to increase learning motivation in students of State Islamic Junior High School 6 Bantul. The type of research is experimental research. The research design uses quasi-experiment. The design uses Non-equivalent Control Group Design. The research population was 8th grade students of State Islamic Junior High School 6 Bantul, amounting to 149 students. The sampling technique in the research used purposive sampling. The criteria for determining the sample in the research are students of State Islamic Junior High School 6 Bantul at 8th grade which indicated to have low learning motivation. The data collection method uses a scale of learning motivation that has gone through validation processes. Data analysis using non-parametric statistics with the Wilcoxon Signed Rank Test. The results showed that there were differences in the results of the experimental group's learning motivation before $(M=72.17)$ and after $(111.67)$ the treatment was given $(p=0.027<0.05)$. These results can be concluded that cognitive restructuring techniques are effective to increase students learning motivation.
\end{abstract}

\section{INTRODUCTION}

Junior high school students are individuals who have a developmental category in adolescence. Adolescence is a time of change and individual development from childhood to adulthood. According to Santrock (2014) adolescence is marked by growth, sexual development psychologically to determine the thoughts, feelings and behavior. The task of adolescent development is important for a young individual to adjust to the social environment.

Important developmental tasks are owned by individuals in adolescence in more mature relationships according to age, sex, social emotional and behavioral change (Manning, 2002). It is one of the demands that must be completed by an adolescent to meet the developmental task's objectives. To meet its needs, motivation is needed in maximizing aspects of adolescent development. According to Santrock (2014), individuals are expected to be able to change behavior in meeting their needs which include various aspects; such as social, cognitive, physical and emotional aspects. having a motivation becoming a challenge for developing youths to influence thein progression task.

Having a motivation becoming a challenge for developing youths to influence thein progression task. In general there are two motivations, namely intrinsic motivation and extrinsic motivation. Intrinsic motivation includes responsibility, diligence, and independence

How to cite:

E-ISSN:

Published by:
Astuti, L., \& Wangid, M. (2020). The Effectiveness of Cognitive Restructuring Techniques on Improving Student Learning Motivation. Islamic Guidance and Counseling Journal, 3(2), 75-82. https://doi.org/10.25217/igcj.v3i2.658

2614-1566

Institut Agama Islam Ma'arif NU (IAIMNU) Metro Lampung 
in in learning activities. Whereas extrinsic motivation encompasses as appreciation and encomfortable enviorement (Schreglmann, 2018). Motivation has an important role in eliciting the affective nature and students' perceptions about the behavior of learning success (Drakulić, 2019). Lack of motivation in students will be a failure in a job. According to Skaalvik \& Skaalvik (2017) the lack of attation, minimal self efficacy and sensitivity of an individual can cause the lack of motivation. Besides motivation they also gets influence from the surrounding environment such as peer influence, competence and independence in learning (Tanaka, 2017).

The phenomenon of lack of learning motivation found in State Islamic Junior High School 6 Bantul is based on preliminary studies and interviews with the teacher of guidance and counseling that listens to students who stated that they often talk with friends during lessons, feel lazy, do not like some specific subjects, do not do homework assignments and feel learning is not important. Some of them say that learning is a pressure because their parents demands great expectations in academic to their children thus, the levels of learning motivation can affect the failure of the learning process. Based on the author's observation, idle students who are still in the process of acquiring new knowledge find it hard to become active and will treat every activity as a burden. Various studies in Indonesia show there are still students who have low learning motivation. Research related to low learning motivation includes Industrial Engineering and Industrial Refrigeration students. Only about $30 \%$ of students have good learning methods and high encouragement to learn, while $70 \%$ of other students have good learning methods but low learning encouragement (Mappeasse, 2009). In addition, there are still junior high school students who are known to have low learning motivation during the transition from elementary school to secondary school by $80 \%$ (Yu, $\mathrm{Wu}$, \& Huang, 2018). Based on a preliminary study conducted by researchers at Islamic junior high School 6 in Bantul using the Checklist of Problems in $8^{\text {th }}$ class, it was found out that there were problems related to low motivation to learn. The overall results related to learning motivation includes $58.1 \%$ of irregular student learning time, $64.5 \%$ of students feel sleepy when the learning process is on going, $38.7 \%$ of students often feel lazy to learn and $29 \%$ of students learns fast during evening. Individuals who have no motivation will be easily discouraged, easily bored and have difficulty in achieving learning goals. Low motivation to pick up new knowledge will have an impact on the achievement of student learning outcomes, this means that issues related to student motivation is of an important concern. Therefore, the teacher guidance and counseling is expected to help students overcome their problems related to low learning motivation.

Motivation in individuals is an encouragement to move an action in bringing about the desire to learn. Learning motivation is the driving force to conduct learning activities and maintain them without being asked by others (Tentama, Subardjo, \& Abdillah, 2019). Individuals with high learning motivation tend to have a strong desire to perform tasks, are able to strive to learn, have persistence in learning, and are enthusiastic in learning (Setiani, Sanjaya, \& Jatmiko, 2019). On the other hand, individuals with low learning motivation certainly cannot carry out learning activities optimally (Fitri, et al., 2016). High and low individual motivation plays a role in determining actions to achieve improved learning outcomes (Rehman \& Haider, 2013). This is proven by a research which claims that learning motivation acts as one of the main keys to an individual's academic success (Rahardjanto, Husamah, \& Fauzi, 2019). Learning motivation has a clear direction on learning behavior. It is a factor that influences behavior and learning outcomes to describe individual cognition in completing tasks and the active component in responding to an individual's emotional towards certain tasks (Sun \& Lee, 2016). Therefore, the incentives will give learning outcomes in accordance with the expectations desired by each individual. The negative impact of learning motivation can be overcome by providing services through guidance and counseling. 
According to Hartini \& Ariana (2016) guidance and counseling teachers or advisors are facilitators that will help a student to change behavior because some of them need help from others to make progress in learning. Various service strategies make students interact to solve problems through group dynamics, one of them with group counseling services. Group counseling is a service where a group of members come because they have a problem being experienced (Jacobs, Masson, \& Harvill, 2012). Group counseling services also help students to make plans and implement them in the future (Smith, 2015). In aiding students to overcome challenges, it is necessary to use techniques in group counseling.

Cognitive restructuring techniques are apprpoaches in which the counselee collaboratively identifies irrational thoughts and evaluates and modifies irrational thoughts that can worsen emotional behavior (Wenzel, Dobson, \& Hays, 2016). According to Clark (2013) through cognitive restructuring techniques, it will change what affects an individual's negative thoughts and encourage more positive beliefs. Changes in judgments about individual beliefs are the process of action from negative beliefs to more positive beliefs. Cognitive restructuring techniques can also make the counselee aware that mistakes in thinking will damage behavioral habits that affect emotional stress (Nursalim, 2013). Provision of cognitive restructuring techniques for students is not only successful in school lessons but also successful in other aspects (Mikaeili, Zare, \& Alhashem, 2010). Various studies explain that cognitive restructuring techniques can reduce academic anxiety (Ghamari, Rafeie, \& Kiani, 2015), change smoking behavior in adolescents (Umaru et al., 2014), improve student's self confidence (Chandra, Wibowo, \& Sunawan, 2019), reduce student's truancy (Erfantinni et al., 2019), and endurance (Krisnayana, 2014). There is no specific research mentioned above about motivation to learn, so the authors in this article will reveal the effect of cognitive restructuring techniques on student learning motivation.

\section{METHODS}

This study is an experimental study with a Non Equivalent Control group design pattern. Campbell \& Stanley (2015) explained that this design was an experimental group and the control group were two different groups given pre-test and post-test. The reason for using this design is because there is a comparison group to see the effectiveness of providing group counseling through cognitive restructuring techniques.

The population in this study was the class VIII students of State Islamic Junior High School 6 Bantul, amounting to 149 students. The sampling technique in this study used purposive sampling. The criteria for determining the sample in this study were eighth grade students of State Islamic Junior High School 6 Bantul, which showed that they had low learning motivation problems based on measurement with learning motivation scale instruments.

Learning motivation scale adopts Schreglmann's theory (2018). The scale of learning motivation consists of two indicators: 1) Intrinsic motivation, namely individual awareness in an activity without the need for external gifts that are marked by having responsibility in their own activities, persevering in their duties and being independent in conducting learning activities. 2) Extrinsic motivation is a factor that influences from outside because it has the effect of appreciation in learning and a good environment. Learning motivation scale consisting of 48 items found 10 items are invalid so that the total number of valid statement product is 30 items and has a low validity value of 0.371 and a high validity value of 0.648 .

Example of the statements are 1) "I do my work in a hurry before being collected", 2) "When discussing problems in the group, I am actively involved in getting reference sources", 3) "I complete the task in an inappropriate time", 4) "I complete the task not according to the time available", 5) "When I get a difficult task, I am embarrassed to discuss it with friends", 6) "I set hours of study at home", 7) "I go to school aimlessly in learning achievement", 8) "I 
get poor learning results because I don't study", 9) "I am active in class because I see the atmosphere of the participating class", and 10) "I find it hard to learn because it is difficult to refuse my friends to hang out", with the Alpha Cronbach formula the reliability coefficient on the learning motivation scale is 0.89 .

The data analysis techniques in this study used non-parametric statistics with the Wilcoxon Signed Rank Test. The purpose of using this data analysis technique is to see changes in student motivation before and after getting treatment in the form of cognitive restructuring techniques.

\section{RESULTS AND DISCUSSION}

The results of the study prove that after the treatment was given to the experimental group there was an increase, while the control group did not have a significant change. Differences in the experimental and control groups can be seen from the results of the hypothesis test analysis presented in Table 1.

\begin{tabular}{lccc}
\hline Measurement & & Experiment $(\mathrm{N}=6)$ & Control $(\mathrm{N}=6)$ \\
\hline Pretest & $\mathrm{M}$ & 72.17 & 72.50 \\
& $\mathrm{SD}$ & 2.317 & 1.871 \\
Posttest & $\mathrm{M}$ & 111.67 & 73.33 \\
& $\mathrm{SD}$ & 15.578 & 2.160 \\
& $\mathrm{Z}$ & -2.207 & -9.49 \\
& $\mathrm{P}$ & $0.027(<0,05)$ & $0.343(>0,05)$ \\
\hline
\end{tabular}

Table 1. Mean, SD, and hypothesis analysis

Based on the data presented in Table 1, the Wilcoxon test results in the learning motivation of the experimental group above explained that $\mathrm{Z}$ was $-2,207$ and probability $\mathrm{p}=0.027$. This shows that the value of $\mathrm{p}=0.027$ is less than 0.05 ( $5 \%$ error rate), it can be concluded that there are differences in the results of the experimental group's learning motivation before and after treatment is given. While the Wilcoxon test results of learning motivation in the control group $\mathrm{Z}$ is -0.949 and probability $\mathrm{p}=0.343$. This shows that the value of $\mathrm{p}=0.343$ is greater than 0.05 ( $5 \%$ error rate), so it can be concluded that there is no difference in the results of learning motivation in the control group before and after the treatment is given.

Learning motivation is essential for students because it encourages learning behavior, clearly and directed to achieve optimal learning outcomes. Research conducted by Riswanto \& Aryani (2017) revealed that students who are motivated to do something will use cognitive skills to be able to master and absorb material well. The researcher identifies the conditions of students' learning motivation that have a tendency to learn motivation in the low category. Various phenomena that occur in the field seem to need intervention to overcome the problems of students who have low learning motivation so that students can be active and able to encourage the power to take action on strong learning activities. Individuals with high learning motivation are effective in determining how individuals achieve desired goals either consciously or unconsciously (Slameto, 2003). Students with high motivation to learn tend to work hard and not easily discouraged (Shiu, Lin, \& Chien, 2012). Increased student motivation can be seen from intrinsic learning motivation by observing the model through video recording and self-monitoring that is able to improve the observed skills (Zulfa, 2018). Research conducted by Tseng \& Walsh Jr (2013) explains learning motivation can increase high after being given the implementation of ARCS (attention, relevance, self-confidence and satisfaction). The existence of motivation in a person will grow depending on every activity. Students who have strong intrinsic motivation and values will have higher scores in learning (Rabanaque \& Martínez-Fernández, 2009). In addition, Aritonang (2008) explains that high 
and low learning motivation possessed by individuals greatly influences academic results. Individuals who have low learning motivation will avoid challenging tasks (Santrock, 2014). They will also be grouped into 2 parts the experimental group will be given cognitive restructuring techniques and the control group will get the usual treatment given by the guidance and counseling teacher.

Cognitive restructuring techniques are provided for students to have high learning motivation. In line with the results of research from Ningrum (2018), it shows that students who are treated in the form of cognitive restructuring techniques have increased motivation in learning office administration studies. The provision of cognitive restructuring techniques can make students have high learning motivation through structuring individual mindsets. Increased student motivation based on research results (Ngwoke, Numonde, \& Ngwoke, 2013) recommends that workshops and seminars should be held in schools in training teachers how to restructure students' cognitive in class to increase orientation towards low achievement. Cognitive restructuring techniques can strengthen the counselee's belief that statements influence behavior by trying to help individuals behave more adaptively by modifying their thoughts (Asikhia, 2014). Changes in individual way of thinking can be done by providing opportunities to imagine the achievement of academic success that is exemplified in student motivation. Cognitive restructuring techniques are also able to overcome the use of self-statements and arguments that make individuals see it as irrational in their behavior and can find more positive ways to encourage pressure and trust in the future (Oghenevwede, 2019).

Learning motivation is the drive to get the academic grades desired by students. Motivation has involvement and commitment in learning to get superior academic value in the achievement of students in the future (Ullah, Sagheer, Sattar, \& Khan, 2013). The results of this study aim to encourage student learning behavior that is only limited to one variable. Research limitations focus on students' cognitive factors that influence student learning motivation. In this study, there are limited to student motivation variables, therefore researchers can then conduct research with encouragement variables in learning success.

The results of this study aim to encourage student learning behavior that is only limited to one variable. Research limitations focus on students' cognitive and factors that influence student learning motivation and in this study are limited to student motivation variables, therefore researchers can then conduct research with motivation variables in learning success. In addition, the effectiveness of cognitive restructuring techniques to provide teacher guidance and counseling can help deal with issues related to learning motivation so that students' learning motivation increases well and can contribute to and knowledge in guidance and counseling practices.

\section{CONCLUSIONS}

Cognitive restructuring techniques are effective to improve student's learning motivation. It helps students become more adaptive, which turns irrational thoughts into positive ones. Hypothesis results showed a significant probability and different mean value of learning motivation, so that there are significant differences in the results of learning motivation of the experimental group before and after the treatment is given.

\section{ACKNOWLEDGMENTS}

The author would like to thank the principal of State Islamic Junior High School 6 Bantul, the school counselors, the students who joined the service of the experimental and control groups and to everyone who contributed to their thoughts in completing this research. 


\section{AUTHOR CONTRIBUTION STATEMENTS}

All authors have agreed with the final version of this article.

\section{REFERENCES}

Aritonang, K. T. (2008). Minat dan motivasi dalam meningkatkan hasil belajar siswa. Jurnal pendidikan penabur, 7(10), 11-21. Retrieved from Google Scholar

Asikhia, O. A. (2014). Effect of Cognitive restructuring on the reduction of Mathematics anxiety among senior secondary school students in Ogun State, Nigeria. International Journal of Education and Research, 2(2), 1-20. Retrieved from Google Scholar

Campbell, D. T., \& Stanley, J. C. (2015). Experimental and quasi-experimental designs for research. Ravenio Books. Retrieved from Google Scholar

Chandra, E. K., Wibowo, M. E., \& Sunawan, S. (2019). Cognitive Behaviour Group Counseling with Self-Instruction and Cognitive Restructuring Techniques to Improve Students' Self-Confidence. Islamic Guidance and Counseling Journal, 2(1), 11-17. https://doi.org/10.25217/igcj.v2i1.305

Clark, D. A. (2013). Cognitive restructuring. The Wiley handbook of cognitive behavioral therapy, 1-22. https://doi.org/10.1002/9781118528563.wbcbt02

Drakulić, M. (2019). Exploring the Relationship between Students' Perceptions of the Language Teacher and the Development of Foreign Language Learning Motivation. Theory and Practice in Language Studies, 9(4), 364-370. https://doi.org /10.17507/tpls.0904.02

Erfantinni, I., Febriani, R., Ningrum, D., \& Melinda, V. (2019). Character Building Through Counseling: The Reducement of Truancy with Cognitive Restructuring Technique. Islamic Guidance and Counseling Journal, 2(2), 77-82. https://doi.org/10.25217/igcj.v2i2.464

Ghamari, K. H., Rafeie, S. H., \& Kiani, A. R. (2015). Effectiveness of cognitive restructuring and proper study skills in the reduction of test anxiety symptoms among students in Khalkhal Iran. American Journal of Educational Research, 3(10). 1230-1236. Retrieved from Google Scholar

Hartini, N., \& Ariana, A. D. (2016). Psikologi konseling: Perkembangan dan penerapan konseling dalam psikologi. Surabaya: Airlangga University Press. Retrieved from Google Scholar

Jacobs, E. E., Masson, R. L., Harvill, R. L., \& Schimmel, C. J. (2011). Group counseling: Strategies and skills. Cengage learning. Retrieved from Google Scholar

Krisnayana, T. A. (2014). Penerapan Konseling Kognitif dengan Teknik Restrukturisasi Kognitif Untuk Meningkatkan Resiliensi Siswa Kelas XI IPA 1 SMA Negeri 3 Singaraja. E-Journal Undiksa Jurusan Bimbingan Konseling, 2(1). Retrieved from Google Scholar

Manning, M. L. (2002). Havighurst's developmental tasks, young adolescents, and diversity. The Clearing House, 76(2), 75-78. https://doi.org/10.1080/00098650209604953

Mappeasse, M. Y. (2009). Pengaruh cara dan motivasi belajar terhadap hasil belajar programmable logic controller (PLC) siswa kelas III jurusan listrik SMK Negeri 5 Makassar. Jurnal Medtek, 1(2), 1-6. Retrieved from http://www.academia.edu/download/41759083/M._Yusuf_Mappeasse.pdf

Mikaeili, N., Zare, H., \& Alhashem, A. (2010). Study of the efficacy of cognitive restructuring teaching at student's attribution style and academic performance. Iranian Rehabilitation Journal, 8(2), 43-49. Retrieved from Google Scholar

Ngwoke, D. U., Numonde, D., \& Ngwoke, A. N. (2013). Effect of Cognitive Restructuring Intervention Programme on Academic Self-Efficacy of LowAchieving Students In 
Bayelsa State, Nigeria. Paripex-Indian Journal of Research, 2(9), 57-60. Retrieved from Google Scholar

Ningrum, S. D. (2018). Keefektifan Teknik Restrukturisasi Kognitif Untuk Meningkatkan Motivasi Belajar Peserta Didik Kelas XI Administrasi Perkantoran SMK $N 1$ Banyudono Boyolali. (Master's Thesis, Universitas Sebelas Maret). Retrieved from Google Scholar

Nursalim, M. (2013). Strategi dan intervensi konseling. Jakarta: Akademia Permata. Retrieved from Google Scholar

Oghenevwede, O. E. (2019). Effects of Cognitive Restructuring on Students' Academic Achievement in Science in Ughelli North Local Government Area of Delta State. ATBU Journal of Science, Technology and Education, 7(1), 123-129. Retrieved from Google Scholar

Rabanaque, S., \& Martínez-Fernández, J. R. (2009). Conception of learning and motivation of Spanish psychology undergraduates in different academic levels. European Journal of Psychology of Education, 24(4), 513. https://doi.org/10.1007/BF03178765

Rahardjanto, A., Husamah, H., \& Fauzi, A. (2019). Hybrid-PjBL: Learning Outcomes, Creative Thinking Skills, and Learning Motivation of Preservice Teacher. International Journal of Instruction, 12(2), 179-192. https://doi.org/10.29333/iji.2019.12212a

Rehman, A., \& Haider, K. (2013). The impact of motivation on learning of secondary school students in Karachi: An analytical study. Educational Research International, 2(2), 139147. Retrieved from Google Scholar

Riswanto, A., \& Aryani, S. (2017). Learning motivation and student achievement: description analysis and relationships both. COUNS-EDU: The International Journal of Counseling and Education, 2(1), 42. https://doi.org/10.23916/002017026010

Santrock, J. W. (2014). Adolescence, Ed 15 th. US: McGraw-Hill Education. Retrieved from Google Scholar

Schreglmann, S. (2018). Developing Academic Motivation Scale for Learning Information Technology (AMSLIT): A Study of Validity and Reliability. Journal of Education and Learning, 7(4), 145-153. https://doi.org/10.5539/jel.v7n4p145

Setiani, R., Sanjaya, I., \& Jatmiko, B. (2019). ARICESA as an Alternative Learning Model to Improve Learning Motivation and Understanding of Student Concepts. International Journal of Instruction, 12(2), 383-398. https://doi.org/10.29333/iji.2019.12225a

Shiu, S. C., Lin, S. Y., \& Chien, H. O. (2012). The Relationship Between Learning Motivation and Innovative Behavior in the University Students: From the Perspective of Creative Self-Efficacy. International Journal of Arts \& Sciences, 5(5), 33. Retrieved from Google Scholar

Skaalvik, E. M., \& Skaalvik, S. (2017). Dimensions of teacher burnout: Relations with potential stressors at school. Social Psychology of Education, 20(4), 775-790. https://doi.org/10.1007/s11218-017-9391-0

Slameto. (2010). Belajar dan Faktor-Faktor yang Mempengaruhinya. Jakarta: PT Rineka Cipta. Retrieved from Google Scholar

Smith, R. L. (2015). A contextual measure of achievement motivation: Significance for research in counseling. VISITAS Online. Retrieved from Google Scholar

Sun, J. C. Y., \& Lee, K. H. (2016). Which teaching strategy is better for enhancing antiphishing learning motivation and achievement? The concept maps on tablet PCs or worksheets?. Journal of Educational Technology \& Society, 19(4), 87-99. https://www.jstor.org/stable/10.2307/jeductechsoci.19.4.87

Tanaka, M. (2017). Examining EFL vocabulary learning motivation in a demotivating learning environment. System, 65, https://doi.org/10.1016/j.system.2017.01.010

130-138. 
Tentama, F. Subardjo, S., \& Abdillah, M. H. (2019). Motivation to Learn and Social Support Determine Employability among Vocational High School Students. International Journal of Evaluation and Research in Education, 8(2), 237-242. https://doi.org/10.11591/ijere.v8i2.18188

Tseng, H., \& Walsh Jr, E. J. (2016). Blended versus Traditional Course Delivery: Comparing Students' Motivation, Learning Outcomes, and Preferences. Quarterly Review of Distance Education, 17(1), 43-52. https://doi.org/10.1017/CBO9781107415324.004

Ullah, M. I., Sagheer, A., Sattar, T., \& Khan, S. (2013). Factors Influencing Students Motivation to Learn in Bahauddin Zakariya University, Multan (Pakistan). International Journal of Human Resource Studies, 3(2), 90. https://doi.org/10.5296/ijhrs.v3i2.4135

Umaru, Y., Abdullahi, M. I., Oliagba, O., Sambo, S., \& Abdulwahid, U. (2014). The effect of cognitive restructuring intervention on tobacco smoking among adolescents in senior secondary school in Zaria Kaduna State, Nigeria. European Scientific Journal, 10(5). Retrieved from Google Scholar

Wenzel, A., Dobson, K. S., \& Hays, P. A. (2016). Cognitive behavioral therapy techniques and strategies. American Psychological Association. Retrieved from Google Scholar

Yu, F. Y., Wu, W. S., \& Huang, H. C. (2018). Promoting Middle School Students' Learning Motivation and Academic Emotions via Student-Created Feedback for Online StudentCreated Multiple-Choice Questions. The Asia-Pacific Education Researcher, 27(5), 395-408. https://doi.org/10.1007/s40299-018-0398-x

Zulfa, I. (2018). Efektivitas Konseling Kelompok Teknik Modeling Terhadap Efikasi diri Akademik dan Motivasi Belajar Siswa Kelas VIII di MTs Maarif Dlingo Bantul. (Master's Thesis, Universitas Negeri Yogyakarta). Retrieved from Google Scholar

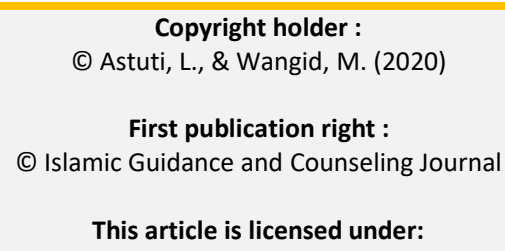

